\title{
Pregnancy Luteoma - A Rare Case Report
}

\author{
Aruna Mallangouda Biradar ${ }^{1}$, Neelamma Girish Patil², Shreedevi Somashekar ${ }^{3}$, \\ Shivakumar Pujeri ${ }^{4}$, Suvarna Santosh Nandi ${ }^{5}$ \\ 1, 2, 3, 4, 5 Department of Obstetrics and Gynaecology, Shri B.M. Patil Medical College, \\ BLDE (Deemed to Be) University, Karnataka, India.
}

\section{PRESENTATION OF CASE}

A 22 year old primigravida with full term pregnancy with morbid obesity and short stature presented to us with complaints of labour pains six hours prior to admission. Her dating, anomaly and term growth scan showed a single live intrauterine foetus with foetal heart rate, amniotic fluid and growth parameters corresponding to the gestational age with no significant anomalies and normal adnexa.

Following a thorough examination and pelvic assessment, diagnosis of cephalopelvic disproportion was made and the patient was posted for emergency caesarean section. A healthy male baby of weight $3.5 \mathrm{Kg}$ extracted and the placenta and membrane were expelled in toto. Uterus was closed in double layer. On examination of adnexal structures, a right sided ovarian mass of around $10 \times 8 \times 6$ $\mathrm{cms}$ of size, solid in consistency and proliferative in appearance was found. Suspecting it to be a malignancy and due to the unavailability of frozen section facility, a right sided oophorectomy was performed, and the specimen was sent for histopathological reporting which revealed a diagnosis of pregnancy luteoma of ovary.

\section{CLINICAL DIAGNOSIS}

Luteoma of pregnancy.

\section{DIFFERENTIAL DIAGNOSIS}

1. Granulosa cell tumour.

2. The comas.

3. Stromal hyperthecosis.

4. Unclassified sex cord stromal tumours.

5. Stromal luteoma.

6. Hyper reaction luteinalis.

7. Leydig cell tumour.
Corresponding Author: Dr. Neelamma Girish Patil, Professor, Department of Obstetrics and Gynaecology, Shri B.M. Patil Medical College, Bijapur, Karnataka, India.

E-mail: neelamma.patil@bldedu.ac.in

DOI: $10.14260 / \mathrm{jemds} / 2020 / 672$

How to Cite This Article:

Biradar AM, Patil NG, Somashekar S, et al. Pregnancy luteoma - a rare case report. J Evolution Med Dent Sci 2020;9(41):30673069, DOI: 10.14260/jemds/2020/672

Submission 02-07-2020,

Peer Review 02-09-2020,

Acceptance 08-09-2020,

Published 12-10-2020.

Copyright (C) 2020 Aruna Mallangouda Biradar et al. This is an open access article distributed under Creative Commons Attribution License [Attribution 4.0 International (CC BY 4.0)] 


\section{DISCUSSION}

Luteoma of pregnancy is a non-neoplastic lesion of the ovary occurring in pregnancy, is incidentally diagnosed during caesarean section or during puerperal tubal ligation. ${ }^{1}$ It was first described by Sternberg and Barelay in 1966 and till now less than 200 cases have been reported in literature. ${ }^{2}$ Most of the cases revert back to pre-pregnant state following delivery. ${ }^{3}$ An accurate diagnosis of pregnancy luteoma is necessary to avoid unnecessary surgical oophorectomy and association of co-morbid risk to both mother and the foetus. ${ }^{4}$ The most obvious symptoms of luteoma is masculisation of mother and possible masculisation of the foetus.5,6 This occurs due to release of testosterone by luteoma.

Testosterone released from the luteoma of pregnancy leads to male characteristics such as growth of dark hair, acne and deepening of voice, ${ }^{7}$ even though it is present in small amounts in females. Even though it's not a life-threatening condition, the association of male characteristics can cause visible changes in mother and has drastic effects on the formation of foetus. The pregnancy luteomas can lead to ambiguous sex in the foetus born.

Luteoma of pregnancy being a rare and benign neoplasia of ovary but may present as a malignant tumour rarely. It was first described by Sternberg and Barelay in 1966 and till now less than 200 cases have been reported in the literature. ${ }^{2}$ And most of the cases revert back to pre-pregnant status following delivery. ${ }^{2}$ The most obvious symptom of luteoma is masculisation of the mother and possible masculisation of the foetus. This mainly occurs due to the release of testosterone. The testosterone released from luteoma leads to male characteristics such as growth of dark hair, acne and deepening of voice and clitoral enlargement, even though it is present in small amounts in females.

Though, it's not a life-threatening condition, the association of male characteristics can cause visible changes in mother and has drastic effects on the formation of foetus. The pregnancy luteomas can lead to ambiguous sex in the foetus born. During pregnancy, the circulating testosterone levels increase by about seven times in comparison with women without pregnancy. This leads to virilisation. The highest testosterone level was $12400 \mathrm{ng} / \mathrm{dL}^{8}$ whereas the normal testosterone level in $3^{\text {rd }}$ trimester of pregnancy is $200-700 \mathrm{ng}$ / dL. Along with this dihydrotestosterone and urinary 17 ketosteroids may also be elevated in these patients.

Masculisation of female infants born to the women with luteoma of pregnancy is seen in 60 to $70 \%$. The maternal Androgen levels are usually higher when compared to the infants who have lower or normal levels. It does not affect the Male infants. Unaffected female infants are assumed to be protected by the P - 450 aromatase cytochrome of placenta which helps in conversion to oestrogens from androgens. When the ability of the placenta to convert the excessively produced testosterone by the tumour to oestrogen is hampered, the risk of masculisation of the female infant is increased. ${ }^{9}$

At 7 to 12 weeks of gestational age, the embryo of female urogenital tract has more receptors for androgens, which leads to genital tract ambiguity, fusion of labioscrotal region and also clitoromegaly. masculisation and transient clitoromegaly without ambiguity is observed after 14 weeks of gestational age. ${ }^{10}$

Diagnosis and follow up of this condition should be made with non-invasive methods like ultrasound scan where the luteoma appears as solitary, solid and multinodular mass, could be unilateral or bilateral with or without haemorrhage. Because of gravid uterus, the image quality might be poor. Hence, magnetic resonance could pose as a better imaging modality.

The management of luteoma of pregnancy differs as they have varied presentation clinically, different characters of the mass, the period of gestation at presentation and the choice of the patient. There is no role of medical management. Generally, the adnexal masses are addressed surgically around 14 to 18 weeks of gestation, the main indications being prevention of ovarian torsion and malignancies. ${ }^{11}$
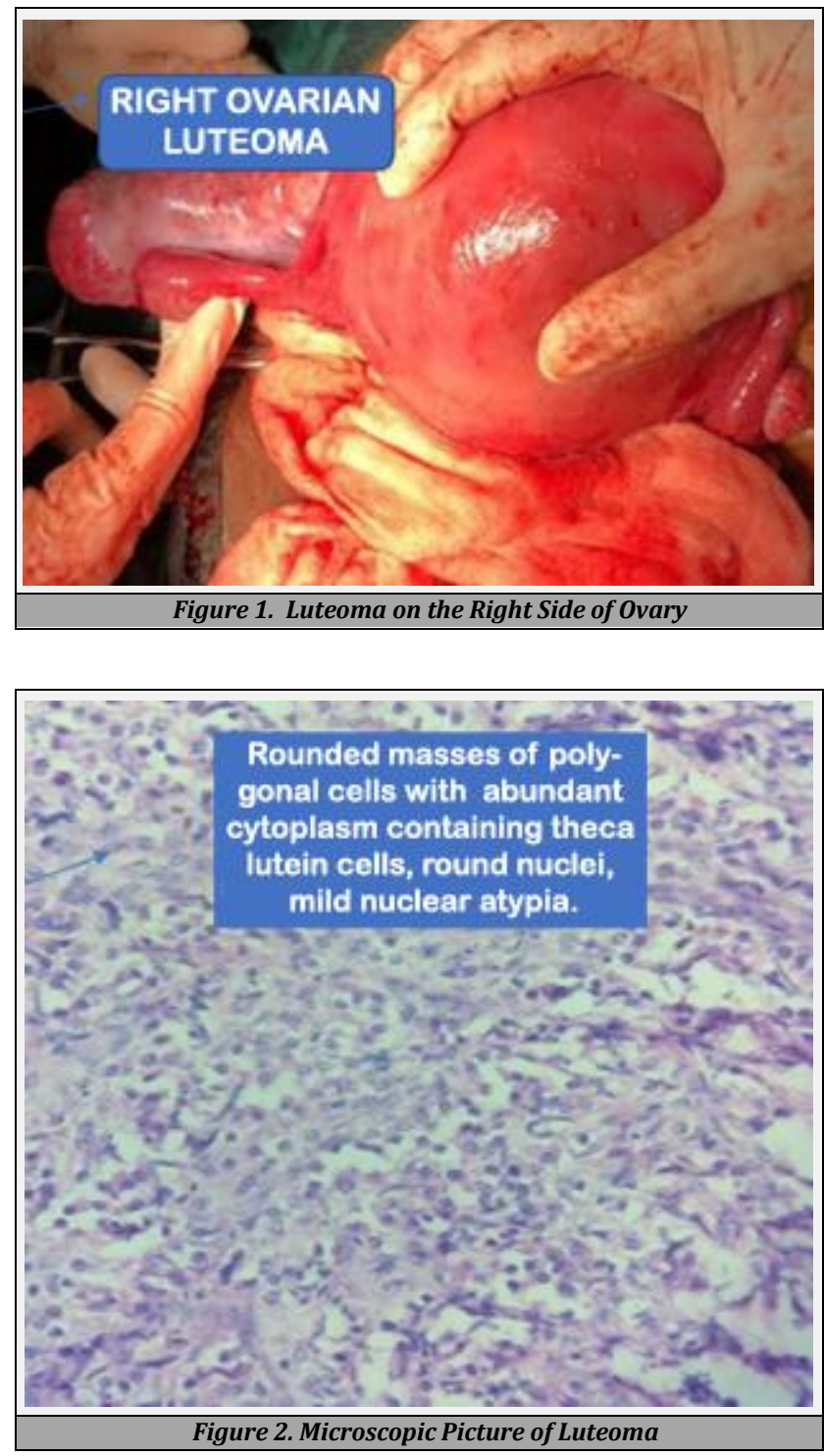

CONCLUSIONS

The luteoma of pregnancy is a rare condition which presents due to altered hormonal environment and presents as either solid or complex cystic neoplasm. It may also present with atypical parameters. Biopsy of this lesion intra-operatively 
with frozen section may help in preservation of ovary. In pregnancies with adnexal mass, pregnancy luteoma should be considered. Conservative management should be considered, when the clinician is skeptic of pregnancy luteoma as they regress spontaneously.

\section{FINAL DIAGNOSIS}

Luteoma of pregnancy.

Financial or other competing interests: None.

Disclosure forms provided by the authors are available with the full text of this article at jemds.com.

\section{REFERENCES}

[1] Nanda A, Gokhale UA, Pillai GR. Bilateral pregnancy luteoma: a case report. Oman Med J 2014;29(5):371-2.

[2] Kumar RV, Ranjan DS, Rao B, et al. Maternal luteoma of pregnancy: a rare case report. J NTR University Health Sci 2014;3(4):267-9.

[3] Zitzmann M, Nieschlag E. Testosterone levels in healthy men and the relation to behavioural and physical characteristics: facts and constructs. Eur J Endocrinol 2001;144(3):183-97.

[4] Hackney AC, Sinning WE, Bruot BC. Hypothalamicpituitary- testicular axis function in endurance- trained males. Int J Sports Med 1990;11(4):298-303.
[5] Masarie K, Katz V, Balderston K. Pregnancy luteomas: clinical presentations and management strategies. Obstet Gynaecol Surv 2010;65(9):575-82.

[6] Chen $\mathrm{CH}$, Chen IC, Wang YC, et al. Boy born after gender preselection following successive gestational androgen excess of maternal luteoma and female disorders of sex development. Fertil Steril 2009;91(6):2732.e5-7.

[7] Manganiello PD, Adams LV, Harris RD, et al. Virilization during pregnancy with spontaneous resolution postpartum: a case report and review of the English literature. Obstet Gynecol Surv 1995;50(5):404-10.

[8] Hartmann U, Mader A, Petersmann G, et al. Verhalten von Herzfrequenz und Laktat wahrend ruderspezifischer Trainingsmethoden. Dtsch Z Sportmed 1989;40:200-12.

[9] Keizer H, Platen P, Koppeschaar H. Blunted $\beta$-endorphin responses to corticotropin releasing hormone and exercise after exhaustive training. Int J Sports Med 1991;12:97.

[10] Lehmann M, Baumgartl P, Wiesenack C, et al. Training overtraining, influence of a defined increase in training intensity on performance, catecholamines and some metabolic parameters in experienced middle- and longdistance runners. Eur J Appl Physiol Occup Physiol 1992;64(2):169-77.

[11] Lehmann M, Dickhuth HH, Schmid P. et al. Plasma catecholamines, beta- adrenergic receptors and isoprotenerol sensitivity in endurance trained and nonendurance trained volunteers. Eur J Appl Physiol Occup Physiol 1984;52(4):362-9. 